\title{
Improving Students' Spatial Ability by Using Macromedia Flash on Geometry Materials
}

\author{
Muhammad Yani ${ }^{1^{*}}$, and Fatemah Rosma ${ }^{2}$ \\ ${ }^{1}$ Departement of Mathematics Education, Muhammadiyah Aceh University, Banda Aceh, Indonesia \\ ${ }^{2}$ Departement of Biology Education, Muhammadiyah Aceh University, Banda Aceh, Indonesia \\ "Corresponding author: muhammad.yani@unmuha.ac.id | Phone Number: +6285260988177
}

\section{ARTICLE HISTORY}

Received : 16 March 2020

Revised : 28 March 2020

Accepted : 8 April 2020

\section{KEYWORDS}

Spatial Ability; Macromedia Flash; Geometry

\begin{abstract}
Every student must have and develop spatial abilities to be successfull in learning geometry. The rapid development of technology also allows teachers to use macromedia flash as an alternative in developing and improving students' spatial abilities. This study aimed to determine and describe the improvement of the students' spatial ability after getting geometry material by using macromedia flash at MTsN Model Banda Aceh. This research used a quantitative approach with a quasi-experimental design and one group pretest posttest design. The population of this study was all students of class VIII MTsN Model Banda Aceh with random sampling as the sample selection techniques so that the selected sample was the students of class VIII-5. The data collection in this study was carried out using a spatial ability test consisted of pretest and posttest questions. The gained data were analyzed with SPSS version 17 with paired sample t-test and percentage. The results showed that there was an improvement in students' spatial ability after having geometry material learning by using macromedia flash at MTSN Model Banda Aceh. Besides, the improvement of students' spatial ability based on indicator of perception spatial was $61.1 \%$, mental rotation indicator was $55.6 \%$, and indicator of visualization spatial was $66.7 \%$.
\end{abstract}

This is an open access article under the CC-BY-SA license.

\section{INTRODUCTION}

One of the mathematical materials that must be mastered by students is geometry. NCTM (Petrus, 2017) stated why geometry needs to be taught at schools because: (1) the world is built by form and space; (2) formal geometry is very helpful for students who experience abstraction problems; (3) it helps to solve the problems in other fields of mathematics; and (4) it helps students think visually. Furthermore, NCTM (2000) also stated that the purpose of geometry taught at schools is that students can use visualization; they have spatial abilities and geometry modeling to solve problems. In the context of the national curriculum in Indonesia, geometry is also a material that must be studied from elementary to high school level. Even more or less $40 \%$ of geometry material is studied at the junior high level. However, to study geometry, especially the geometry of space, spatial abilities are needed.

The National Academy of Science (2006) stated that each student must develop spatial abilities and its sense which are very useful in understanding the relations and the nature of geometry to solve mathematical problems. Spatial ability is an important factor to be succeeded in geometry (Battista, 1990; Battista \& Clements, 1996; 1991, Battista, Wheatley \& Talsma, 1982). Spatial ability can be defined as the ability to evoke, maintain, regain, and change well-structured visual images (Lohman, 1993). De Lange (2003) also said that spatial ability is the ability that supports understanding of the world (3D) which requires an understanding of the nature of objects, relative positions and other things related to spatial. Whereas Linn and
Petersen (1985) declared that spatial ability is a mental process in perceiving, storing, remembering, creating, changing and communicating the shape of space which is then grouped into three categories, namely (1) spatial perception, (2) mental rotation, and (3) spatial visualization. Gutierrez (1997) and McGee (1979) state that there are two main abilities in spatial ability, namely spatial orientation and spatial visualization.

Spatial ability is not only important and needed in the study of mathematics, especially geometry, but it is also highly needed in other cross-science contexts. Strong and Roger (2002) stated that in industrial technology, spatial capabilities are very useful in simulation, multimedia, and modeling. Spatial ability is also very important for chemistry (Pribyl \& Bodner, 1987), physics (Pallrand \& Sbeer, 1984), engineering (Yue, 2002; Gonzalez, et.al, 2016), and astronomy, education, geography, geosciences, and psychology (National Academy of Science, 2006). As a result, adequate guidance and attention are needed from all parties, especially teachers as an effort to develop students' spatial abilities as required in the curriculum.

This is because there are still facts in the field that show students are still difficult in solving geometrical problems that demand spatial ability. Hidayat and Mirza (Nursyahidah, 2016) said that there are still many students who experience difficulties in learning geometry. Furthermore Bustang, Zulkardi, Darmawijoyo, Dolk, \& Van Eerde (Septia, Prahmana, Pebrianto, and Wahyu; 2018) stated that geometry is one of the problematic materials because it requires spatial ability. The 
results of interviews of mathematics teachers who teach in class VIII MTsN Model Banda Aceh (2018) also stated that the dominant student get difficulty in geometry especially space geometry. This is why students' spatial abilities need to be considered and improved in learning geometry.

Based on the results of a preliminary study in class VIII of the MTsN Model Banda Aceh, it is found that $72 \%$ of students had difficulty in solving geometry problems that demanded spatial ability. One of the reasons is that the students are not accustomed to solve the problems that demand spatial abilities such as spatial perception, mental rotation, and spatial visualization. As a result, indicators identify spatial structures vertically or horizontally, identify spatial structures and elements which their position have been manipulated by rotating the shapes, and identify the composition of spatial structures in which changes or movements have not been achieved yet.

One possible alternative that can help students to improve spatial ability in geometry material is by designing the learning process by using macromedia flash. This is because macromedia flash can make the learning more interesting and make it easier for students to imagine in understanding spatial features that are useful in solving every geometry problems.

Macromedia flash is an application that is used to design presentation devices, publications, or other applications that require the availability of means of interaction with the use of projects built with flash, can consist of texts, images, simple animations, videos, or other effects (Wahono, 2002 ). Simbolon, Mulyono, and Syahputra (2017) also said that the use of macromedia flash can help teachers to design and develop instructional media in the form of animation that can be played with flash movies, aimed to facilitate the students in understanding and identifying mathematical problems provided by the teacher.

The results of Guzel and Gunhan's (2010) research on prospective mathematics teachers' views about using flash animations in mathematics lessons concluded that teachers agree on the importance of using flash animation in mathematics. The results of the three teachers interviewed showed a paradigm change in using flash animation in mathematics from pre-interview and post-interview which showed the importance of technology integration into mathematics learning. The result of a research conducted by Simbolon, Mulyono, and Syahputra (2017) about the efforts to improving the mathematical critical thinking student's ability through problem solving learning strategy by using macromedia flash also obtained results: (a) the application of learning with the problem solving approach using macromedia flash can improve students' critical thinking skills. This can be seen from the achievement of increased learning outcomes obtained $40 \%$ in the first cycle to $60 \%$ in the second cycle, and $80 \%$ in the third cycle. b) the ability of teachers to manage learning with the problem solving approach using macromedia flash in both categories in the third cycle with an achievement of $87.5 \%$.

Based on the opinions and results of previous studies above, the use of macromedia flash in mathematics learning in geometry material is possible to improve students' spatial abilities. The expected goal of this research is to find out and describe the improvement of students' spatial ability after having geometry material learning by using macromedia flash at MTSN Model Banda Aceh.

\section{RESEARCH METHOD}

This research used quantitative approach with a quasi-experimental research design with one group pretest posttest design. Arikunto (2010) stated that one group pretest posttest design is an experimental model carried out in one group only by comparing the results of the initial test with the final test. The population in this study was all students of class VIII MTsN Model Banda Aceh, while in selecting the sample, random sampling techniques was used and it was students of class VIII-5.

The learning instrument used was the lesson plan, student worksheet, and teaching materials in macromedia flash form. While the data collection instrument is a spatial ability test in description item form developed based on the indicators of spatial ability as presented in Table 1 below.

Table 1. Spatial Ability Indicator

\begin{tabular}{|c|c|c|}
\hline $\begin{array}{l}\text { Spatial } \\
\text { Ability }\end{array}$ & $\begin{array}{c}\text { The Measured } \\
\text { Ability }\end{array}$ & Indicator \\
\hline $\begin{array}{l}\text { Perception } \\
\text { Spatial }\end{array}$ & $\begin{array}{l}\text { Observing a } \\
\text { geometry or } \\
\text { elements of } \\
\text { geometry }\end{array}$ & $\begin{array}{l}\text { Identifying the position of } \\
\text { geometry vertically or } \\
\text { horizontally }\end{array}$ \\
\hline $\begin{array}{c}\text { Mental } \\
\text { Rotation }\end{array}$ & $\begin{array}{l}\text { Rotating a } \\
\text { geometry }\end{array}$ & $\begin{array}{l}\text { Identifying the geometry } \\
\text { and elements that have } \\
\text { been manipulated by } \\
\text { rotating the position }\end{array}$ \\
\hline $\begin{array}{l}\text { Visualizati } \\
\text { on Spatial }\end{array}$ & $\begin{array}{l}\text { Visualizing or } \\
\text { manipulating a } \\
\text { geometry }\end{array}$ & $\begin{array}{l}\text { Identifying the composition } \\
\text { of the geometric in which } \\
\text { there is a change or } \\
\text { displacement }\end{array}$ \\
\hline
\end{tabular}

While the data collection in this study was carried out using tests consisting of pretest and posttest which analyzed using SPSS version 17 and the statistical test used paired sample t-test at a significance level of $5 \%$.

\section{RESULTS AND DISCUSSION}

Based on the results of the analysis of pretest and posttest data, the average spatial ability of students in geometry material before and after having learning material by using macromedia flash was 40.19 and 83.92 . The normality test result of pretest and posttest also shown normal distribution data. Furthermore, an analysis was performed to see the increase of students' spatial ability after having material learning by using macromedia flash used paired sample t-test at a significance level of $5 \%$. The research hypothesis tested in this study was that there is an increase of students' spatial ability after getting learning by using macromedia flash on geometry material at MTsN Model Banda Aceh.

The formulation of the statistical hypothesis is as follows:

$\mathrm{H}_{0}$ : There is no improvement in students' spatial ability after getting learning by using macromedia flash on geometry material at MTsN Model Banda Aceh.

$\mathrm{H}_{\mathrm{a}}$ : There is an improvement in students' spatial ability after getting learning by using macromedia flash on geometry material at MTsN Model Banda Aceh.

The results of data analysis using paired sample t-tests can be seen as presented in Table 2 below. 
Table 2. The Result of Hypothesis Test by Paired Sample t-Test

\begin{tabular}{|c|c|c|c|c|c|}
\hline \multicolumn{3}{|c|}{ Paired Differences } & \multirow[b]{2}{*}{$\mathrm{t}$} & \multirow[b]{2}{*}{$\mathrm{df}$} & \multirow{2}{*}{$\begin{array}{c}\text { Sig. } \\
\text { (2-tailed) }\end{array}$} \\
\hline Mean & $\begin{array}{c}\text { Std. } \\
\text { Deviation }\end{array}$ & $\begin{array}{l}\text { Std. Error } \\
\text { Mean }\end{array}$ & & & \\
\hline-43.7 & 6.7 & 1.1 & -39.1 & 35 & .000 \\
\hline
\end{tabular}

Based on the results of the hypothesis test presented in Table 2 above it can be seen that the value of sig. $<$ a or $0.00<$ 0.05 , so based on the criteria $\mathrm{H}_{0}$ testing was rejected or Ha was accepted. As a result it can be concluded that there is an improvement of students' spatial ability after learning by using macromedia flash on geometry material at MTsN Model Banda Aceh. The improvement of students' spatial ability on geometry material in this study shows that the students can understand well the given or taught spatial concepts in geometry by using macromedia flash. This is also supported by the result of research by Simbolon, Mulyono, and Syahputra (2017) concluded that the application of learning with problem solving approaches using macromedia flash can improve students' critical thinking skills. The result of the study (Liberna and Nusantari, 2018; Umam and Yudi, 2016) also concluded that there was an improvement of students' mathematics learning achievement after being taught by using macromedia flash.

The improvement of students' spatial ability in this study is also inseparable from the advantages found in macromedia flash that can make interactive buttons with a movie or other object, make changes in color transparency in movies, make changes in animation from one form to another, make movements animation by following a predetermined path, and can be converted and published into several types including .swf, .html, .gif, .jpg, .png, .exe, .mov. The thing that happened in learning by using macromedia flash at the time of the research was also grabed the students' interesting, curiosity, and motivation to learn due to the display of learning material could be understood easily by the movement of the animations.

Learning by using macromedia flash can also illustrate geometrical shapes in various conditions and positions, so that the spatial ability or spatial of students can really be sharpened. Because before learning by using macromedia flash students had not been able to imagine higher and felt difficulty in imagining if the geometry space is rotated, visualized or manipulated in various forms, and identified the vertical and horizontal position of the geometry.

Another effect of the design of teaching materials in the form of macromedia flash is also very helpful for students to be able to learn independently from teaching materials that have been made in flash flexibly and what students have already imagined can be seen visually. This is relevant to Pesonen's statement (Guzel and Gunhan, 2010) stated that using macromedia flash is an important start in connecting abstract mathematics to the concrete or vice versa, so that learning mathematics is more meaningful.

The improvement of students' spatial ability is based on the indicators of spatial ability as presented in Table 3 below.
Table 3. Improving Student' Spatial Ability Based on Indicators

\begin{tabular}{|c|c|c|c|c|c|}
\hline \multirow[b]{2}{*}{ No } & \multirow[b]{2}{*}{$\begin{array}{l}\text { Spatial } \\
\text { Ability }\end{array}$} & \multirow[b]{2}{*}{ Indicator } & \multicolumn{3}{|c|}{ Persentage (\%) } \\
\hline & & & $\begin{array}{l}\text { Pre- } \\
\text { test }\end{array}$ & $\begin{array}{c}\text { Post- } \\
\text { test }\end{array}$ & $\begin{array}{c}\text { Improve } \\
\text { ment }\end{array}$ \\
\hline 1 & $\begin{array}{c}\text { Perception } \\
\text { Spatial }\end{array}$ & $\begin{array}{l}\text { Identifying the } \\
\text { position of } \\
\text { geometry } \\
\text { vertically or } \\
\text { horizontally }\end{array}$ & 25,0 & 86,1 & 61,1 \\
\hline 2 & $\begin{array}{c}\text { Mental } \\
\text { Rotation }\end{array}$ & $\begin{array}{l}\text { Identifying the } \\
\text { geometry and } \\
\text { elements that } \\
\text { have been } \\
\text { manipulated } \\
\text { by rotating the } \\
\text { position }\end{array}$ & 19,4 & 75,0 & 55,6 \\
\hline 3 & $\begin{array}{c}\text { Visualizatio } \\
\text { n Spatial }\end{array}$ & $\begin{array}{l}\text { Identifying the } \\
\text { composition of } \\
\text { the geometric } \\
\text { in which there } \\
\text { is a change or } \\
\text { displacement }\end{array}$ & 13,9 & 80,6 & 66,7 \\
\hline
\end{tabular}

The data also can be presented in the form of the percentage bar charts of the students' spatial ability improvement based on indicators as in Figure 1 below.

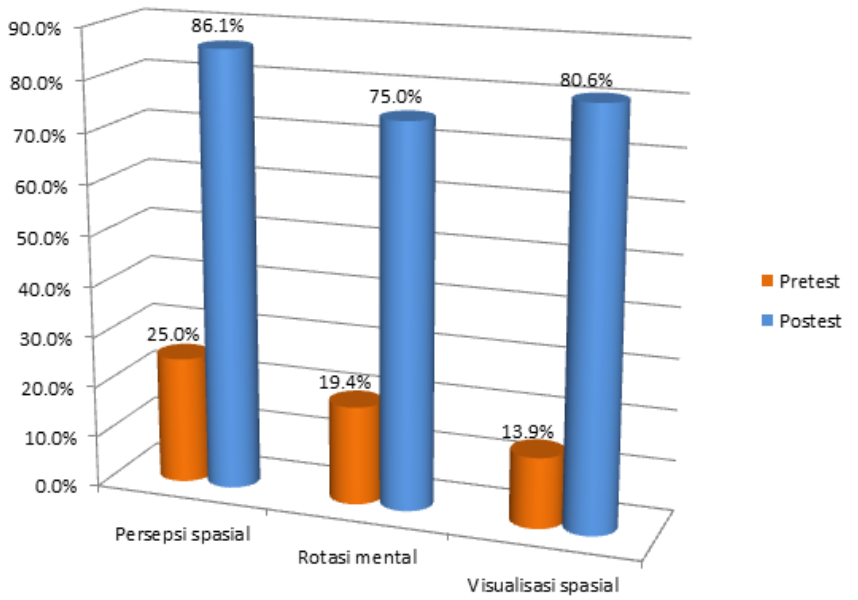

Fig 1. The Percentage of the Improvement of Students' Spatial Ability.

Based on the bar chart above it can be seen that the spatial ability of the students on perception spatial before learning by using macromedia flash was $25.0 \%$ and after learning was $86.1 \%$ with an improvement obtained was about $61.1 \%$. Spatial ability in mental rotation before learning by using macromedia flash was $19.4 \%$ and after having it was about $75.0 \%$ with an improvement about $55.6 \%$. The spatial ability of the students in visualization spatial before learning by using macromedia flash was about $13.9 \%$ and after learning was about $80.6 \%$ with an improvement of $66.7 \%$.

The success in an effort to improve students 'spatial ability in this study, using macromedia flash, which is a computer application relevant to the result of Syahputra's research (2013) concluded that a realistic mathematics learning approach on the topic of geometry with the help of a 3- $D$ cabri computer program can improve students' spatial 
ability at school categorized as good and medium. Likewise, realistic mathematics learning approaches can improve the spatial ability of students who have high, intermediate and low background of former math abilities. In addition to this, there is an influence between the learning approach and school categories on improving students' spatial ability. Nurkholis's research result (2012) also concluded that the achievement and improvement of students 'spatial sense abilities who obtained computer-aided problem-based learning were better than the achievement and improvement of the abilities of students who obtained conventional learning and the achievement and improvement of students' spatial sense abilities in both classes was classified in medium level.

\section{CONCLUSION}

Based on the results of the data analysis and the discussion that have been described, it can be obtained the following conclusions: (1) There is an improvement of students' spatial ability after having geometry material learning by using macromedia flash at MTsN Model Banda Aceh. (2) Improvement of students' spatial abilities based on indicators obtained that: (a) for indicator of perception spatial, the improvement obtained about $61.1 \%$, (b) for mental rotation indicator, the improvement obtained by $55.6 \%$, and (c) for visualization spatial indicator, an improvement of $66.7 \%$ was obtained.

\section{ACKNOWLEDGEMENTS}

The author would like to thank profusely to the Directorate of Research and Community Service, the Directorate General of Research and Technology Strengthen and Development of the Ministry of Research, Technology, and Higher Education of Republic of Indonesia (Direktorat Riset dan Pengabdian Masyarakat, Direktorat Jenderal Penguatan Riset dan Pengembangan Kementerian Riset, Teknologi, dan Pendidikan Tinggi Republik Indonesia) for providing financial support in conducting this research.

\section{REFERENCES}

Arikunto, S. (2010). Manajemen Penelitian. Jakarta: Rineka Cipta.

Battista, M. T. (1990). Spatial Visualization and Gender Differences in High School Geometry. Journal for Research in Mathematics Education, 21, 47-60.

Battista, M. T., \& Clements, D. H. (1991). Research Into Practice: Using Spatial Imagery in Geometric Reasoning. Arithmetic Teacher, 39, 18-21.

Battista, M. T., \& Clements, D. H. (1996). Students' Understanding of Three-Dimensional Rectangular Arrays of Cubes. Journal for Research in Mathematics Education, 27, 258-292.

Battista, M.T., G. Wheatley, \& G. Talsma. (1982). The Importance of Spatial Visualization and Cognitive Development for Geometry Learning of Pre-Service Elementary Teachers. Journal for Research in Mathematics Education, 13, 332-340.

De Lange, J. (2003). Mathematic for Literacy. Dalam Madison, B., \& Steen, L. (Eds), Quantitative Literacy: Why Numeracy
Matters for School and Cholleges. (pp. 75-89). USA: National Council on Education and the Diciplines

Gonzalez, Roca, C., Gutierrez, Jorge, M., Dominguez, M. G., \& Carrodeguas, M. C. M. (2017). Virtual Technologies to Develop Visual-Spatial Ability in Engineering Students. EURASIA Journal of Mathematics Science and Technology Education, 13(2), 441-468

Gutierrez, A. (1997). Visualization in 3-Dimensional Geometry: In Search of a Framework. Proceeding of the 20th Conference of the International Group for the Psychology of Mathematics Education, 1-19.

Guzel, E. B. \& Gunhan, B. C. (2010). Prospective Mathematics Teachers' Views about Using Flash Animations in Mathematics Lessons. International Journal of Educational and Pedagogical Sciences, 4 (3), 210-215

Liberna, H. \& Nusantari, D. O. (2018). The Influence of Macromedia Flash Learning on the Students' Mathematic Concept Understanding. Journal of Mathematics Education (JME), 3(1), 1-6

Linn, M., \& Petersen, A. (1985). Emergence and Characterization of Sex Differences in Spatial Ability: A Meta-Analysis. Child Development, 56 (6), 1479-1498.

Lohman, D. F. (1993). Spatial Ability and G. Paper presented at the First Spearman Seminar, University of Plymouth, July 21, 1993

McGee, M. G. (1979). Human Spatial Abilities: Psychometric Studies and Environmental, Genetic, Hormonal, and Neurological Influences. Psychological Bulletin, 86 (5), 889-918.

National Academy of Science. (2006). Learning to Think Spatially. Washington DC: The National Academics Press.

NCTM. (2000). Principles and Standards for School Mathematics. Reston: National Council of Teachers of Mathematics.

Nurkholis, E. (2012). Meningkatkan Kemampuan Spatial Sense dan Pemecahan Masalah Matematik Siswa SMA melalui Pembelajran Berbasis Masalah Berbantuan Komputer. Tesis, http://repository.upi.edu/9039/

Nursyahidah, F., Saputro, B, A., \& Prayito, M. (2016). Kemampuan Penalaran Matematis Siswa SMP dalam Belajar Garis dan Sudut dengan Geogebra. Suska Journal of Mathematics Education, 2 (1), 13-19

Pallrand, G. J. \& Sbeer, F. (1984). Spatial Ability and Achievement in Introductory Physics, Journal of Research in Science Teaching, 21(5), 507-516

Petrus, Z., Karmila., \& Riady, A. (2017). Deskripsi Kemampuan Geometri Siswa SMP Berdasarkan Teori Van Hiele. Pedagogy, 2(1), 145-160

Pribyl J. R \& Bodner, G. M. (1987). Spatial Ability and Its Role in Organic Chemistry: A Study of Four Organic Courses, Journal of Research in Science Teaching, 24, 229-240.

Septia, T., Prahmana, R. C. I., Pebrianto, \& Wahyu, R. (2018). Improving Students Spatial Reasoning with Course LAB. Journal on Mathematics Education, 9 (2), 327-336

Simbolon, M., Mulyono., \& Syahputra, E. (2017). The Efforts to Improving the Mathematical Critical Thinking Student's 
Ability through Problem Solving Learning Strategy by Using Macromedia Flash. American Journal of Educational Research, 5(7), 725-731

Strong, S. \& Roger, S. (2002). Spatial Visualization: Fundamentals and Trends in Enginering Graphics. Journal of Industrial Technology, 18 (1), 1-6.

Syahputra, E. (2013). Peningkatan Kemampuan Spasial Siwa melalui Penerapan Pembelajaran Matematika Realistik. Cakrawala Pendidikan. 32 (3), 353-364

Umam, K. (2016). Pengaruh Menggunakan Software Macromedia Flash 8 Terhadap Hasil Belajar Matematika Siswa Kelas VIII. Jurnal Pendidikan Matematika, 1(1), 84-92

Wahono. (2002). Multimedia sebagai Media Pembelajaran Interaktif. Semarang: Unnes Press.

Yue, J. (2002). Spatial Visualization Skills at Various Educational Levels. Proceedings of the 2002 American Society for Engineering Education Annual Conference \& Exposition, 7.1014.1-7.1014.10 